Portland State University

PDXScholar

5-10-1974

\title{
Female Alcoholism: the Relationship of Marital Status to Personality Disorganization
}

Julene B. Knapp

Portland State University

Follow this and additional works at: https://pdxscholar.library.pdx.edu/open_access_etds

Part of the Social Work Commons

Let us know how access to this document benefits you.

\section{Recommended Citation}

Knapp, Julene B., "Female Alcoholism: the Relationship of Marital Status to Personality Disorganization" (1974). Dissertations and Theses. Paper 2134.

https://doi.org/10.15760/etd.2131

This Thesis is brought to you for free and open access. It has been accepted for inclusion in Dissertations and Theses by an authorized administrator of PDXScholar. Please contact us if we can make this document more accessible: pdxscholar@pdx.edu. 
AN ABSTRACT OF THE 'THESIS OF Julono B. Knapp for the Mastor of Soclal Work presented May 10, 1974.

Titler Female Alcoholism: The Relationship of Marital Status to Personality Disorganization.

APPROVED BY MEMBERS OF THE THESIS COMMITTEE:

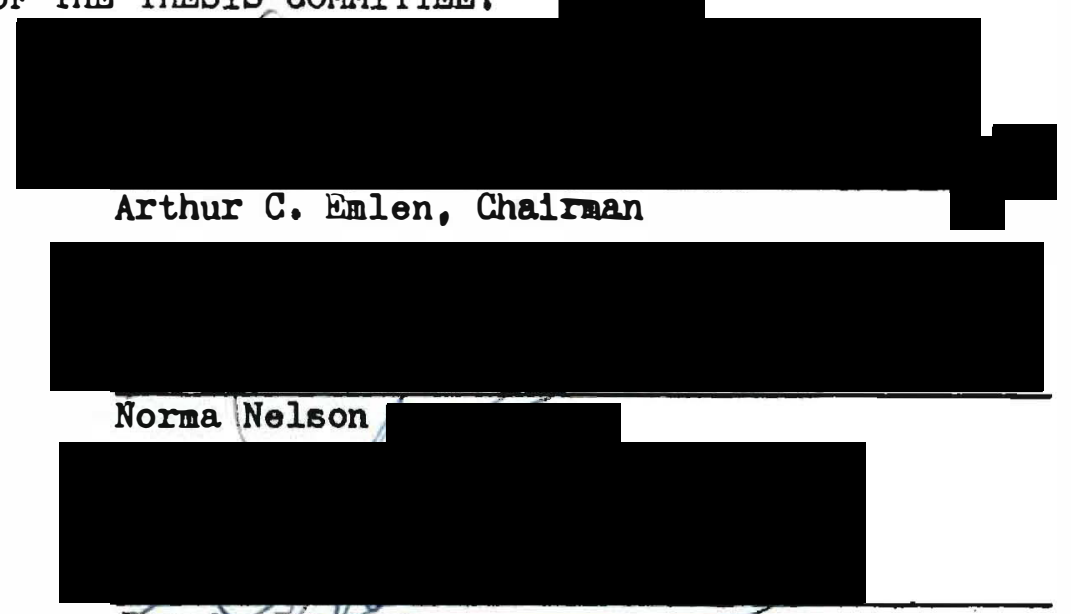

Dennis Brehner

Research on the female alcoholic indicates that women drink for different reasons than men. Rather than being a product of role conflict as it is in males, female alcoholism is frequently precipitated by stress, particularly marital stress. For exploratory purposes a group of women seen at a public alcoholism treatment clinic were divided Into four categories: 1) Non-alcoholic wives of alcoholic men, 2) alcohollc wives of non-alcoholic men, 3) single alcoholic women, 4) alcoholic wives of alcoholic men. These groups were compared for amount of personality disorganization, using the total number of abnormal scales on the clinical profiles of the Minnesota Multiphasic Personality In- 
ventory, a personality test administered at the beginning of treatment. The investigator hypothesized that the alcoholic wives of alcoholics would demonstrate the most aysfunction, due to the unstablilaing effects of the alcoholic husband and the stress of marital interaction between two disorganized personalities. In contrast, the alcoholic woman married to the non-alcoholic husband would experience less stress and consequently less personality dysfunction without the problems created by an alcoholic husband. The dysfunction of the single alcoholic women was hypothesized to fall between the two marltal categorles; and the dysfunction of the non-alcoholic wives of alcoholic males was hypothesized to be the least among the four categories, since these wives have been shown to have essentially normal personalities which become disorganized by their husbands" alcoholic ep1sodes.

As hypothesized, the non-alcoholic wives showed the least amounts of personality disorganization, but the alcohollc women showed an inverse relationship to the hypothesized onder of dysfunction, 1.e. the alcohollc women married to non-alcoholic men were most disorganized, according to numbers of abnormal MMPI scales, followed by single alcohollc women and then the alcoholic wives of alcohollc men. The differences among the alcoholic groups disappeared, though, when age was held constant, except in the group of older alcohollo women, where the inverse relationship remained.

The results of this study raise questions about the adaptive and maladaptive used of alcohol within a marriage situation and the subsequent effects on personality. 
FEMALE ALCOHOLISM, THE RELATIONSHIP OF MARITAL STATUS TO PERSONALITY DISORGANIZATION

by

JULENE B. KNAPP

\begin{abstract}
A thesis submitted in partial fulfillment of the requirements for the degree of

MASTËR

of

SOCIAL WORK
\end{abstract}

Portland State University

1974 
TO THE OFFICE OF GRADUATE SIUDIES AND RESEARCH:

The members of the Comititee approve the thesis of

Julene B. Knapp presented liaj 10, 1974.

Arthur Z. Emlen, Chairman

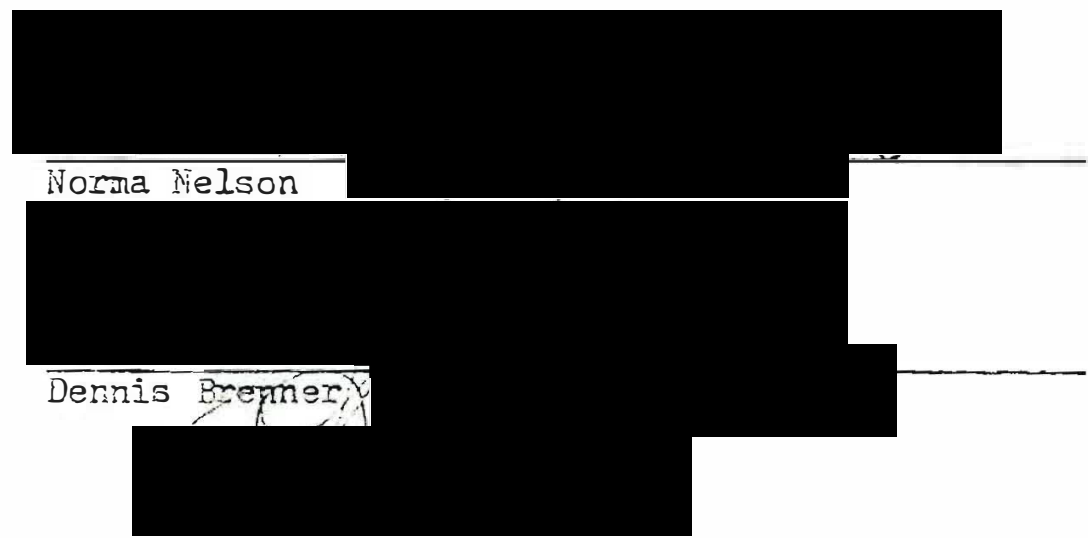

ADPROVR:

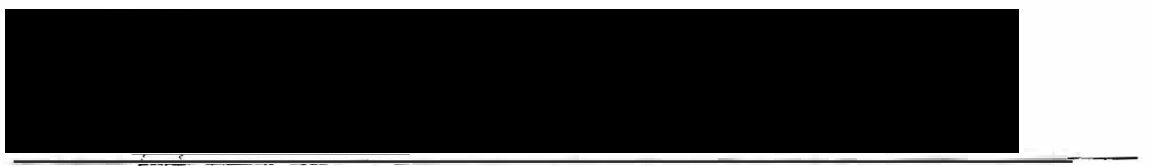

Dean, School of Social tork

Devid T. Clark, Lean of Graduate $S$ 
The following study on female alcoholism was sponsored by the Alcoholism Treament and Training Center in Portland, part of the State Mental Health Division. I wish to express my appreciation to the people at that clinic for the opportunity to do this research. In particular, I would like to thank Mr. Dennis Brenner for many of the 1deas behind this study and for his encouragement and fac1Iitation.

Secondly, I want to thanis Dr. Arthur Eralen, chalrman, and Ms. Norma Nelson for the time they gave to this research as members of my thesis committee. I value very much their 1deas, enthusiasm and support.

Finally, I want to acknowledge the hours of work spent by my co-researcher, my husband $\mathrm{J1m}$, in collecting the data for this study. He will be following up this thesis with further research with the same data. 
TABLE OF CONTENTS

PAGE

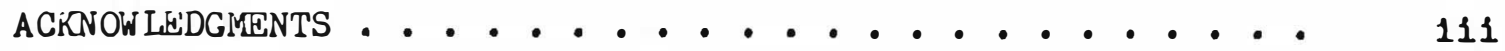

IIST OF TABLES. . . . . . . . . . . . . . . v v

CHAP'PER

I INTRODUCTION . . . . . . . . . . . . . I

II THE LITERATURE. . . . . . . . . . . . . 3

III MARRIAGE AND PERSONALITY DISORGANIZATION. • . . . 8

IV ME'THOD..................... 11

V THE RESULTS . . . . . . . . . . . . 14

VI CONCLUSIONS AND RECOMMENDATIONS . . . . . . 30

REFERENCES . . . . . . . . . . . . . . . . . 32

OTHER SOURCES CONSULTED . . . . . . . . . . . . 35 
LIST OF TABLES

TABLE

PAGē

I Age Distribution of Total Sample.......... 14

II Levels of Education Attained in Total Sample. . . . 15

III Family Income Range in Total Sample . . . . . . 15

IV Marital Status in Total Sample. . . . . . . 16

V Marital Status/Spouse in Total Sample . . . . . 17

VI Frequencies of Invalid Tests. . . . . . . . . 18

VII Numbers of Abnormal Scores per Test in Categories

of Women. . . . . . . . . . . . 19

VIII Chi Square by Cell for Table VII. . . . . . . . 20

IX Numbers of Abnormal Scores per Test for Alcoholic

Women . . . . . . . . . . . . . 21

X Chi Square by Cell for Table IX . . . . . . . . 22

XI Numbers of Abnormal Scores per Age Category . . . . 25

XII Numbers of Abnormal Scores per Test in Young

Alcoholic Women . . . . . . . . . 26

XII Numbers of Abnormal Scores per Test in Middle-

Aged Alcoholic Women . . . . . . . . . 27

XIV Numbers of Abnormal Scores per Test in Older

Alcoholic Women . . . . . . . . . . 27 


\section{CHAPTER I}

\section{INTRODUC'IION}

The professional social worker deals at many levels with the Hidespread problems and consequences of alcoholism. It renders many marriages and families dysfunctional. It is a problem among the depressed, the elderly and the lonely. Its victims are frequently seen in our criminal justice and public welfare systers. Parsons w1th alcoholism in turn produce their own victims - victims of their poor parenting, of their drunken driving, of their crime, or their unsteady employment. The social worker, whether he works at the macrolevel or mezzolevel or microlevel of human organization, encounters the manifestations of alcoholism.

Though research on alcoholism is extensive, most of it has been done on male rather than female populations. The literature avallable on female alcoholics indicates that alcoholism has some unique aspects in women. For example, the onset of alcoholism in women seems to be prec1pitated by a stressful event more often than for men $(1,2,3)$, whereas research on male alcoholics indicates that the dynamics of male alcoholism are in part a response to the male role in society (4). Psychological studies in general have often ignored the differences in male and female and have defined women in terms of men, 1.e. they have described how women are different from men rather than what they are isike in their own right. Frequently these studies portray subtly pejorative 1mages of 
women, especially of the alcoholic woman, who is viewed by many in our culture as immoral and unfeminine $(5,6)$. The majority of the literature on alcoholism, then, has questionable significance when applied to the female.

Furthermore, American women axe currently undergoing extensive examination of traditional feminine roles, creating significant changes both in individual persons and in families. Awareness of both the effects of the traditional roles and of the rapld changes on the propensity for alcoholism is a necessity $(7,8)$. Undoubtedly, marriage, with its concomitant, role expectations, plays a significant part in the lives of most women in American society. Traditionally it has been instrumental in defining a woman's status and lifestyle. Thus, the following study explores some 1ssues in the relationship of marriage to alooholism in romen. 
A review of the research literature on the alcoholic woman provides some data on the family backgrounds and drinking histories of these women. Several studies report that, when these women are compared to populations of male alcoholics, they are found to have a later age of onset with alcoholism beginning around age thirty, about eight years later than in men. Nevertheless, the alcoholism seems to progress more rapidly so that both males and females are first hospitalized near age forty $(9,10,11)$.

Depending on the researcher, rates of broken marriages for these women vary from $24 \%$ found by Winokur (10) to $67 \%$ in Lisansky's (?) study; these are much higher than found in male populations. Often the alcoholic woman's drinking is precipitated by a stressful situation. Rosenbaum (12) and Wood (13) found the most frequent source of this stress to be marital conflict and tension. In an intensive study of merried alcoholic women Rosenbaum found great emotional deprivation in childhood, loss of parents during formative years, and characterization of the mothers of the women as aggressive and strict and the fathers as weak and ineffectual. These women, then, brought strong dependency needs to their marriages - marriages in which they often fourd their husbands also to be weak. The husband's own drinking and uncontructive attitudes toward the wife were the major sources of marltal conflict. 
These marriages, built on previous instability, were further exacerbated by other factors within the marriage.

Wood et al. (13) studied middle and upper class women and found that they were invariably raiser in disturbed homes with a cold, dominant parent (usually the mother) and frequently an alcoholic father. The women grew up with feelings of inadequacy and an inability to directly express hostility. They then marrled men much like their own mothers cold, controlling and unable to express feelings.

Other researchers report that alcoholic women often drink with their husbands, 20 to $40 \%$ of whom are also alcohol abusers $(7,8,14)$. Zelan (15) and Iisansky (7) both found evidence indicating that these women often choose husbands who are much older or younger than themselves. Also, sexual dissatisfaction seems to be common $(13,14,16,17)$. The incidence of alcoholism among first degree relatives of alcoholic females is much higher than in the general population and also higher than the incidence among the relatives of male alcoholics $(9,10)$. In 1957 Lisansky (?) reported that a significantly larger proportion of the females in her outpatient clinic study reported problem drinking among parents and siblings, and among those women who were or had been married, 35\% (as opposed to 9\% among male alcoholics) had spouses with drinking problems. These women seemed to have a relatively good amount of social integration, however, when she compared them to a group of women alcoholics in a penal institution. She found the prison population to be younger and to have historles of more severe deprivation, plus a higher rate of parent, sibling, or spouse drinking problems. Both Gramer (18) and Fort (19) support this, having found higher inci- 
dences of personality problems and antisocial behaviors with earlier ages of onset.

The disorganized personalities of alcoholics have recelved a fair amount of attention in research. The available literature on the personalities of female alcoholics strongly suggests that the alcoholism is frequently associated with other psychiatric dysfunction, especially affective disorders.

Alcoholism and other forms of dependence upon drugs have complex manifestations. Certain personallity features seem to enhance the likelihood of forming such habits, the drugs themselves have demonstrable personality effects on those who use them, and the consequences of such dependence upon other aspects of users lives may in turn cause additional emotional disturbance and upset (20, p. 322).

Schuk1t (9) from Washington University Psychiatry Department studied the importance of affective disorders among female alcoholics. Only 39 from their sample of 70 had alcoholism as their first-appearing (primary) 1liness. Of the others 19 had a pre-existing affective disorder, 6 had pre-existing sociopathy, and 6 had other psychiatric 1llnesses. The first degree female relatives of the probands tended to have the same disonder as the primary disorder in the proband; e.g. a primary affective disorder alcoholic had female relatives with affecHive disorders while primary alcoholics had female relatives with alcoholism. In male alcoholic populations the presence of primary affective disorders is much lower: $3 \%$ as compared to $27 \%$. Males tend to have higher rates of primary personality disorder $(9,10)$. Research on the genesis of alcoholism suggests a wide range of factors contributing to the process. Lisansiky (7), Berner (8), Curran (16) and Wall (II), provide evidence that the developrent is different in 
women than in male alcoholics. They cite problems with psychosexual development and identification with parents. Others describe pathological mechanisus centering around poor impulse control (2l), over indulgence (8), problems with authority figures $(12,13,15)$ and discuption of early home Iife (7). No "alcoholic personality" has been 1solated. Kinsey (6) demonstrated that alcoholism seems to arise when several social and psychological factors coincide. In spite of the fact that about one thind of fenale alcholics are married to men who are also alcohol abusers, the literature on the wife of the male alcoholic gives virtually no attention to the differences between the alcoholism and non-alcoholism of these women. Some of the early reports on the wife of the alcoholic pictured her as an aggressive woman who married an alcoholic in oxder to meet her own need to be dominant. Most of this research was in fact besed on a handful of clinical judgements from therapy done by psychiatrists. In the 1950's this picture evolved into that of a woman whose personality fluctuated with the stresses of her marriage and who generally did not fit into a personal1ty "type." J. K. Jackson (22) in Seattle was instrumental in developing this "Stress Theory" to explain the wife's personality disorganization. The studies of Bailey, Haberman and Alksne (23) in the 1960's have contributed to the formulation of the psychosocial theory which integrates the old psychopathological theories with the stress theory. In their review of the literature on the wife of the alcoholic Edwards, harvey and Whitehead conclude that the wives of male alcoholics are women who have essentially normal personalities of different types, ration than of eny one naticuiar type. They may suffer personality dysfurction when tireir husbinds are active alcoholics, but if their husbands become abstinent 
and the perlods of abstinence increase, the wives experlence less and less dysfunction. Concurrent with these personality fluctuations are changes in the wives' methods

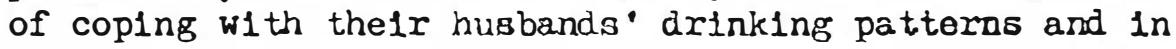
the roles the wives play within the family. In all this, these women seem much like other women experiencing mar1tal problems. . . The only tenable proposition about the wives of alcoholics 18, therefore essentially a null hypothes1s - that 1s, that the wives of alcoholics are not unique (24, p. 130). 
CHAPTER III

\section{MARRIAGE AND PERSONALITY DISORGANIZA'TION}

If the research on the wives of alcoholics can be generalized to Include those wives who are also alcoholics, one would presume that they, too, suffer dysfunction when their husbands are drinking, in addition to their own personality dysfunction. The chances of stressful living would seem to be greater in marriages of this type than in marriages where a non-alcoholic husband could provide some stabilizing factors such as consistent income. Seemingly, the communication between two dysfunctional people would be far more disordered than between a more or less normal spouse with his dysfunctional partner, consequently precipitating the marital stress and tension which leads to alcoholic episodes $(6,12)$.

Wanberg $(25,26)$ and others have found that alcoholic women frequently drink with their spouses possibly this fortifies the denials of each of the partners in the alcoholic marriage and maintains the maladjustment. Since women have traditionally depended for much of their social 1dentity on their spouses, the alcoholic woman married to an alcoholic might find her own poor self lmage worsened by her marital situation. Furthermore, because any recovery from alcoholism depends greatly on one's mate, and because these marrlages do not support recovery, the alcoholism is likely to be maintalned for longer pexiods of time, 1ncreasing the possibility or organic damage $(2,27)$. Thus, all 
of these factors - mar1tal stress, malntenance of denials, poor soc1ally defined self 1mage, and unsupported recovery - 1ncrease the chances of personal1ty disorganization in the alcoholic woman married to the alcohollc man.

Therefore, this investigator hypothesized that these alcoholic women with alcoholic husbands would exh1bit more general personallty disorganieation than alcohollc women who are married to non-alcohollc spouses.

If alcoholism or non-alcoholism in one's spouse affects the personality dysfunction of an alcohollc woman, one must ask what marital status 1 tself contributes to indications of overall personality functioning, 1.e. how are these marrled alcohollc women different in personality dysfunction from single alcoholic women? For the sake of exploratory study the investigator assumed that the amount of personallty dysfunction of single alcohollc women falls somewhere between the degrees found in women marrled to non-alcoholles and women marrled to alcohollcs. A survey of the alcohollc l1terature provides l1ttle to support or discount such an assumption. Fort and Porterfield (28) suggest that women with notable personality difflculties preceding the onset of heavy drinkling have a lower onset age. Non-marrled alcoholics may be e1ther formerly marrled or never marrled, and since never-married women are frequently of that status merely because of their young age, one might assume that at least some of the women in this category exh1b1t personality dysfunction unrelated to alcoholism (29). If the presence of a non-alcohollc spouse is to be considered as a stabilizing factor to the personality of an alcohollc woman, the absence of that stablliz- 
Ing factor would then put the unmarried alcohollc woman on more or less neutral ground.

Returning to the original generalization that the alcoholic wives of alcoholics suffer the similar increased personality disorganization that non-alcoholic wives of alcoholics suffer when their husbands are actively alcohollc, one must also compare these alcohollc women to those essentially normal non-alcoholic wives. As a result, when seen on a continuum of least-to-most dysfunction, the personalities of these women would range from I) non-alcohollc women with alcoholic husbands to 2) alcoholic women with non-alcoholic husbands to 3) single alcoholic women to 4) alcohollc women w1 th alcoholic husbands. 


\section{CHAPTER IV}

\section{METHOD}

The purpose of the research at this point is not to explore the more specific personality characteristics but to measure only general personality dysfunction at the time the woman appeared for treatment. The Minnesota Multiphasic Personality Inventory is a well known instrument which has been used frequently in the study of alcoholic personalities (e.g. in 30), it has some distinct advantages for use in this research and was chosen for this exploratory study to measure degree of disorganization. The test can be quite sensitive to day by day personality changes, and it is often used by cliniclans for that purpose. The MMPI is a self-administering questionnaire which y1elds a proflle with four validity scales and ten clinical scales on a graph of $\mathrm{T}$ scores. The profile distinctly marks scores above 70 and below 30 , these scores are two or more standard deviations from the mean and are generally considered to be abnormal. The higher the score, the greater the similarity to the varlous clinical groups used in constructing the scales. A proper interpretation of the test includes not only the analysis of score elevation but also analysis of the features of the patterns and slopes of the scores as they are connected on the graph. St1ll, research has tended to favor study of "interpretable" scores, 1.e. scores above 70 and below 30. Merely by looking at the abnormal clinical scores one gets a rough ldea of the amount of dysfunction and 
of the areas in which the personality is manifesting statistically abnormal characteristics. Because the type of dysfunction is unimportant at this time, a count of munbers of abnormal clinical scores per test ylelds a simple instrument for measuring personality disorganization. Invalid tests are readily rejected by the elimination of tests with abnormal validity scales.

In sumnary, the investigator chose to measure personality disorganization by comparing the numbers of abnormal scores on the clinical scales or the Minnesota Multiphasic Personality Test.

To examine the relationship of marital status and alcoholism of spouse to personality disorganization, a sample of women treated at the Alcohol Treatment and Training Center, an out-patient clinic operated in Portland, Oregon, by the State Division of Mental Health was chosen. The clinic serves alcoholics and their families in the greater metropolitan Portland area and its mural surroundings, with most clients coming from low and middle income families. Fducation and group therapy are the main treatment modalities. Part of the intake procedure is the administration of the Minnesota Multiphasic Personality Inventory and the Edwards Personal Preference Schedule, and any applicant who has completed the intake and orientation process after the year 1968 usually has the results of these tests available in his or her record. The subjects for this study are the 243 women who completed this intake procedure between 1968 and 1973 and who were no longer being seen at the clinic, 1.e. they were tested at the beginning of treatment and their cases had been closed as of June, 1973. This number does not include the children of the clients and the fourteen non-Caucasion women 
treated during this time span.

The use of a commexcially designed hand cand sorting system allowed the investigator to collect pertinent information in a number of areas, including the scores on their MMPI and Edwands Personal Preference Schedule. By defining the population as to demographic parameters, the problems of some previous research on alcoholic women, cited by Schukit (9) in his review of the literature, can be eliminated. All the information and the diagnoses in the files were reconded by the professional staff at the clinic, using the nationally accepted diagnostic categorles of alcoholism and personality disonders published by the American Psychiatric Association (31). The subjects of this study were anonymous to the investigator. 


\section{CHAPTER V}

\section{THE RESULTS}

As previously mentioned, the demographic parameters of the sample must be taken into account as the results are analyzed. Some frequencies tabulated on the total sample give an overview of the type of women seen in the clinic. TABLE I shows that most of the women were under fifty years of age when they entered the clinic, w1th almost half of ther between the eges of thirty-six and fifty.

TABLE I

AGE DISTRIBUTION OF TOTAL SAMPLE

\begin{tabular}{lcc}
\hline Age-yrs & Frequency & $\%$ of Total \\
\hline $18-35$ & 89 & $37 \%$ \\
$36-50$ & 108 & $44 \%$ \\
51 up & 46 & $19 \%$ \\
Total & 243 & $100 \%$ \\
\hline
\end{tabular}

TABLE II indicates that the women generally have high school educations and that about one in three have some type of advanced train1ns. The category "beyond" may include technical training beyond high school level or eny amount of college work. Only 36 or those 76 were considered to be professionally trained, $\theta \cdot B$. teacher, registered nurse. 
TABLE II

LEVEIS OF EDUCATION ATTAINED

IN TO'TAL SAMPLE

\begin{tabular}{lcc}
\hline \hline Level & Frequency & \% of Total \\
\hline Grammer Sch. & 25 & $10 \%$ \\
High Sch. & 139 & $58 \%$ \\
Beyond & 76 & $31 \%$ \\
Unknown & 3 & $1 \%$ \\
Total & 243 & $100 \%$ \\
\hline
\end{tabular}

TABLE III

FAMILY INCOME RANGE IN TOTAL SAMPLE

\begin{tabular}{lcc}
\hline \hline Income & Frequency & $\%$ of Total \\
\hline Below $\$ 6000$ & 115 & $47 \%$ \\
$\$ 6000-12,000$ & 100 & $41 \%$ \\
Above $\$ 12,000$ & 28 & $12 \%$ \\
Total & 243 & $100 \%$ \\
\hline
\end{tabular}

Most of the women in this sample seem to fall into lower-middle class socio-economic status or below. The very nature of the clinic, a public agency, tends to eliminate those persons who are able to pay for private psychiatric services. Also, many of the clients at the Alcohol Treatment and Training Center are referred by other public agenvies such as the public welfare department. The low femily incomes may 
also be due to employment problems experienced as a result of alcohol1sm.

Only $19 \%$ of the total sample of women were unmarried. This category includes those who have never been married, those who are divorced and those who are widowed. This study looked only at the effects of the marital relationship during the time women entered treatment, and therefore, these women were grouped together since no marltal relationship was being experienced at that time. Because so many of the women in the sample were women coming to the clinic as part of the treatment for their alcoholic husbands, the sample is biased in the direction of the married. TABLE IV shows the frequencies of marriege in the total sample. For the sake of categorization, a handful of women separated from their husbands at the time of intake were considered to be married.

TABLE IV

MARTTAL STATUS IN TOTAL SAMPLE

\begin{tabular}{lcc}
\hline \hline Status & Frequency & $\%$ of Total \\
\hline Married & 196 & $81 \%$ \\
Unnariled & 47 & $19 \%$ \\
Total & 243 & $100 \%$ \\
\hline
\end{tabular}

When these women are divided according to marital status and alcohollsm of spouse, the frequencies for each of the four categories are the following: 
TABLE V

MARITAL STATUS/SPOUSE IN TOTAL

SAMPLE

\begin{tabular}{lr}
\hline \hline Category & Numbar \\
\hline NA (Non-alcoholic wife of alcoholic) & 127 \\
AN (Alcoholic wife of non-alcohollc) & 41 \\
AO (Unmarried alcoholic woman) & 47 \\
AA (Alcoholic wife of alcoholic) & 28 \\
Total & 243 \\
\hline
\end{tabular}

Thus, the figures indicate that over half of the total sample were non-alcoholic women. 1

When the data were gathered on the frequencies of abnormal MMPI scores, a total of 42 subjects rere found to have invalid test results, according to the elevated validity scales. These subjects were eliminated because the investigator, as opposed to the subject's therapist, had no way of interpreting the significance of the individual scores from knowledge of the client. A problem in using the MMPI as a measure of general disorganization is that the appearance of abnormal validity scales says something in itself about personality disorganization. TABLE VI shows from which of the categories the women were dropped because of invalid tests.

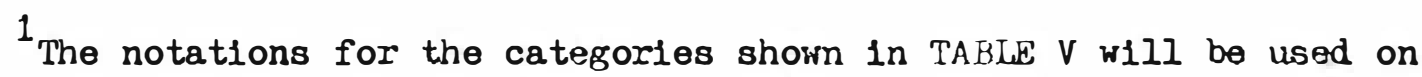
subsequent tables and in the toxt. The fixst letter stands for the woman in the marital dyad: " $N$ " If she is non-alcohollc and "A" if she is alcoholic. The second lettex alonifies the apruse with "N" for non-alcoholic, "A" for alcoholic, and "O" for no spouse. 
'TABLE VI

FREQUENCIES OF INVALID TESTS

\begin{tabular}{lcc}
\hline $\begin{array}{l}\text { Marltal } \\
\text { catogory }\end{array}$ & Froquenay & $\begin{array}{l}\% \text { of Total } \\
\text { Toots por } \\
\text { Category }\end{array}$ \\
\hline NA & 12 & $9.8 \%$ \\
AN & 9 & $23.7 \%$ \\
AO & 16 & $36.4 \%$ \\
AA & 5 & $17.9 \%$ \\
\hline
\end{tabular}

Three quarters of all abnormal scores on the val1d tests (108 of 144 scores) were on women who had four or fewer elevated scores per test. If a koman has five or more scores falling into abnormal ranges, $50 \%$ of the ten possible scales are abnormal and indicate a good amount of disorganization on personality variables. Therefore, the tabulations were coded in the categorles of "0," which is a normal test w1 thout elevated or depressed scores, " $1, "$ Indicating one score in abnormal ranges: "2," for two abnormal scores, etc. through "5+," which Indicates that the tests in that category have five or more abnormal scores. All research on the MMPI demonstrates a marked tendency for scores to fall into elevated rather than depressed ranges; the abnormal scores on this sample likewise fall predominantly above the 70 percentile, so that, for the most part, the categories of numbers of abnormal scores per test represent elevated scores.

TABLE VII arranges the data into the hypothesized order of disorganization, NA having the lesst amount of disorganization, followed by 
AN, then $A O$ and $A A^{1}$

TABLE VII

NUMBERS OF ABNORMAL SCORES PER TEST IN CATEGORIES OF WOMEN

\begin{tabular}{l|c|c|c|c|c|c|c}
\hline \multirow{2}{*}{$\begin{array}{l}\text { Type of } \\
\text { Woman }\end{array}$} & \multicolumn{6}{|c}{ Abnormal Scores per Test } \\
\cline { 2 - 8 } & 0 & 1 & 2 & 3 & 4 & $5+$ & Total \\
\hline NA & 45 & 26 & 16 & 6 & 9 & 13 & 115 \\
\hline AN & 1 & 6 & 7 & 5 & 0 & 10 & 29 \\
\hline AO & 5 & 11 & 4 & 1 & 3 & 4 & 28 \\
\hline AA & 5 & 7 & 5 & 1 & 1 & 3 & 22 \\
\hline Total & 56 & 50 & 32 & 13 & 13 & 30 & 194 \\
\hline Gomms & .203 & Ch1 Square $=34.384$ & df -12 & P<.001 \\
\hline
\end{tabular}

The correlation coefficient Gamma of .203 is statistically significant by chi square test $\left(\pi^{2}=34.384\right.$, df $\left.=12, P<.001\right)$; however, the correlation is low, showing only a very slight increase in personality disorganization as the hypothesized social disorganization increases on the continuum of NA to AA.

The chi square test of significance is shown in TABLE VIII with $x^{2}$ partitioned by cell. The primary sources of variance are circled.

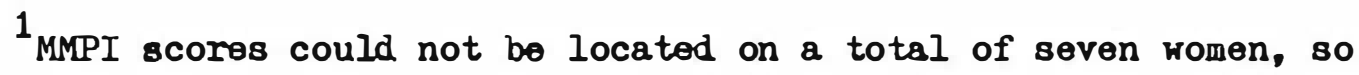
these women were eliminated from the body of this research, leaving a total sasple of 194. 
TABLE VIII

CHI SQUARE BY CELL FOR TABLE VII

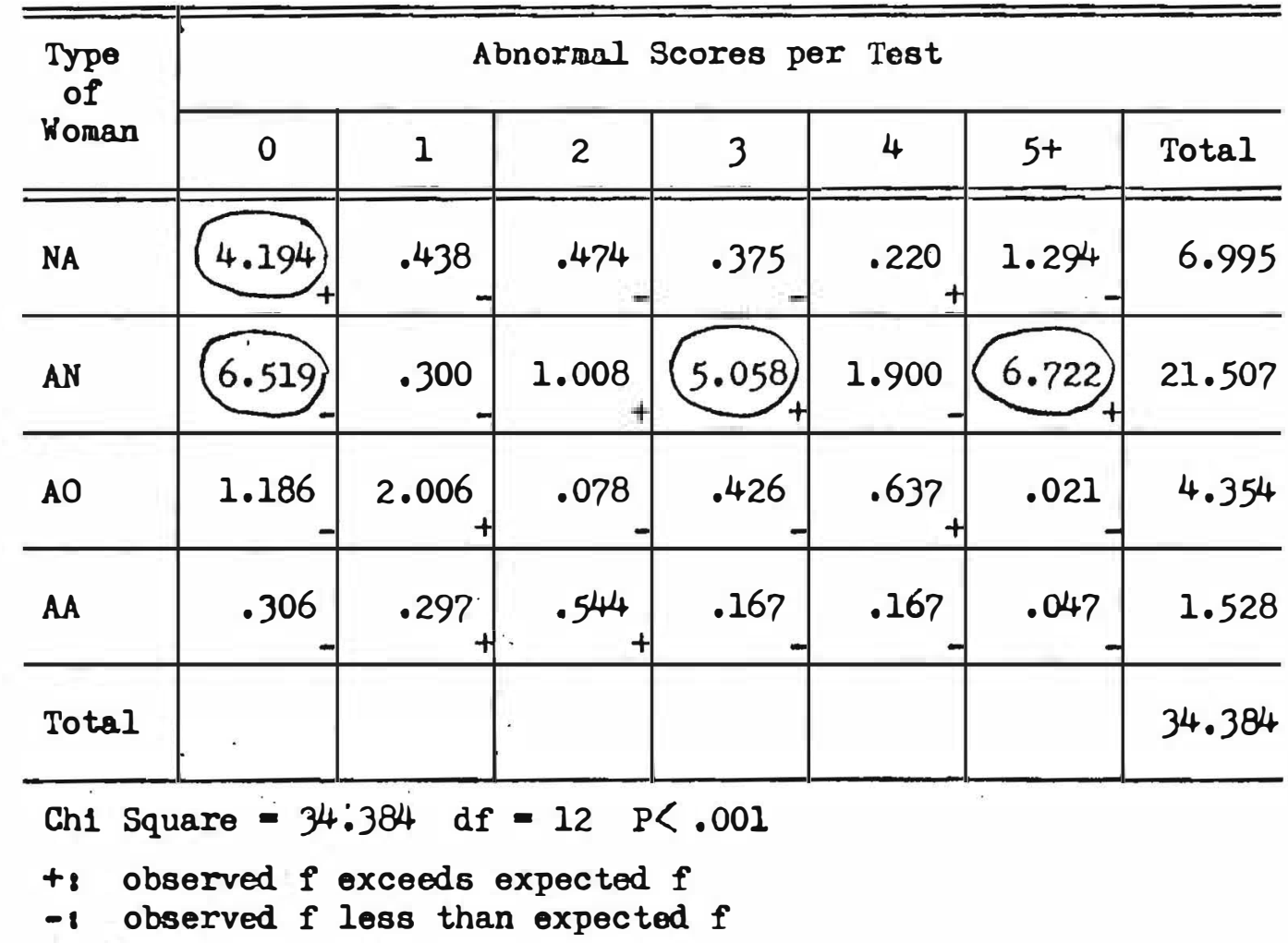

The obtained chl square shows much greater differences among the categories than expected. with most of the differences coming from the NA and AN groups. The greater-than-expected frequency in the "O" category of NA confirms that most of the non-alcoholic wives of alcoholic men are essentially normal. In the AN category the number of normal tests are far fewer than expected, but the tests with three abnormal scores and five abnormal scores are much greater than expected. These results suggest that the data contradict the original hypothesis that AA would show the most personality disorganization, which would put the greatest observed ch1 square differences at the thind and fourth levels. 
Instead, the alcoholic women with non-alcoholic husbands seemingly demonstrate more dysfunction than other alcoholic women.

When these women are grouped according to marital status and alcoholism of spouse, significant differences are demonstrated among the Eroups. However, the inclusion of the NA group may be skewing the results out of proportion, since previous studies indicate, as do these frequenoles, that the non-alcoholics tend to be close to a normal population on personality scores. To check for this possibility, chi square was recomputed after eliminating the NA category. The results are shown in TABLE IX belor.

TABLE IX

NUMBERS OF ABNORMAL SCORES PER TEST FOR ALCOHOLIC

WOMEN ONLY

\begin{tabular}{|c|c|c|c|c|c|c|c|}
\hline \multirow{2}{*}{$\begin{array}{l}\text { Type } \\
\text { of } \\
\text { Woman }\end{array}$} & \multicolumn{7}{|c|}{ Abnormal Scores per Test } \\
\hline & 0 & 1 & 2 & 3 & 4 & $5+$ & Total \\
\hline AN & 1 & 6 & 7 & 5 & 0 & 10 & 29 \\
\hline $\mathrm{AO}$ & 5 & 11 & 4 & 1 & 3 & 4 & 28 \\
\hline AA & 5 & 7 & 5 & 1 & 1 & 3 & 22 \\
\hline Total & 11 & 24 & 16 & 7 & 4 & 17 & 79 \\
\hline
\end{tabular}

TABLE $X$ shows the chl square test by cells with cello of greatest differences circled. 
TABLE $X$

CHI SQUARE BY CELL FOR TABLi' IX

\begin{tabular}{|c|c|c|c|c|c|c|c|}
\hline \multirow{2}{*}{$\begin{array}{l}\text { Type } \\
\text { of } \\
\text { Woman }\end{array}$} & \multicolumn{7}{|c|}{ Abnormal Soores per Test } \\
\hline & 0 & 1 & 2 & 3 & 4 & $5+$ & Total \\
\hline AN & 2.2 & $\begin{array}{r}.891 \\
-\end{array}$ & $\begin{array}{r}.205 \\
+\end{array}$ & $\underbrace{2.215}_{t}$ & 1.500 & $\frac{2.329)}{t}$ & 9.390 \\
\hline $\mathrm{AO}$ & $\begin{array}{r}.310 \\
+\end{array}$ & $\begin{array}{r}.735 \\
+\end{array}$ & $\begin{array}{r}.507 \\
- \\
\end{array}$ & $\begin{array}{r}.900 \\
-\end{array}$ & $\begin{array}{r}1.829 \\
+\end{array}$ & $\begin{array}{r}.667 \\
- \\
\end{array}$ & 4.948 \\
\hline AA & $\begin{array}{r}1.164 \\
+\end{array}$ & $\begin{array}{r}.013 \\
+\end{array}$ & $\begin{array}{r}.056 \\
+\end{array}$ & .426 & $\begin{array}{r}.009 \\
-\end{array}$ & .615 & 2.283 \\
\hline TOTAL & & & & & & & 16.621 \\
\hline $\begin{array}{ll}\text { Ch1 Sc } \\
+8 \text { ol } \\
-8 \text { ol }\end{array}$ & ived & $\begin{array}{l}21 \\
\text { ceeds } \\
38 \text { th }\end{array}$ & $\begin{array}{l}\text { xpecte } \\
\text { expec }\end{array}$ & $=10$ & & 10 & \\
\hline
\end{tabular}

The correlation coefficient Gamma of -.34 , significant at the .1 level, shows that, indeed, the relationship of personality disorgan1zation to the hypothesized order of dysfunction ( $A N$ to $A O$ to $A A$ ) is inverse, 1.e. the women married to alcoholic husbands are least disorganized, the single women are next most disorganlzed, and the women married to non-alcoholics are the most disorganized. The circled ch1 square cells indicate that AN have much fewer numbers of normal tests and much greater numbers of highly disorganized tests than are expected. The positive and negative signs in the cells indicate the general Inverse trend.

The reversal of $A N$ and $A A$ from the orginal hypothesis is supported by the possible differences in disorganization demonstrated in TABLE VI. 
That table shows that more invalid tests were eliminated for the AN group than for the AA group, even though the AO group had the most tests eliminated. 1

Several factors may be generating this inverse trend. Some of these factors could be within the marital situations. The non-alcoholic husband of the alcoholic woman (AN) may not be a source of stabilization but of discord, due to his dissatisfaction with the problems created for him and the children by the wife's drinking. AN may feel more pressure to be secretive and feel more gullt if her drinking is frequently cited as a source of problems. Her husband may be expecting her to fulfill roles she cannot play. His pressure for change in her behavior may not be presented in an effective manner. She may be drinking as a result of pre-existing marital problems. Her husband may actually be encouraging her drinking to relleve her sexual inhibitions or to sat-

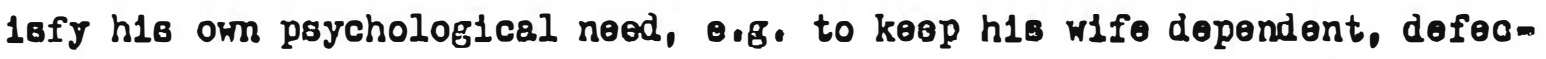
tive, or ineffective $(13,32)$.

On the other hand, the alcoholic wife with the alcoholic husband (AA) may be drinking to please and pacify her husband and to experience some companionship with him. One might hypothesize that for her alcoholism may be a realistic solution to marital problems rather than mere precipitate of marital stress. Her spouse might also exhibit more sympathy and understanding of her problem - if, indeed, it is viewed as a

1 The exact placement of the AO group on the disorganization continuum is not the main issue of this thesis, although the comparison of married to unmarried alcoholics is important. Since the instrurent used to measure anount of dysfunction is designed for exploratory purposes only, the investigator has no way of resolving the difference at thio time。 
problem - even if he does not ald in her recovery. AA women may tend to be primary alcohollcs, having become an alcohollc not because of a personality problem but from long exposure to heavy drinking with a 8pouse. If this 18 the case, these women may have known before thelr marrlages that their husbands abused alcohol and have consequently made a more realistic adjustment in a marriage which meets their needs to some extent. Balley (33) found that many women know thelr husbands may be alcohollcs before they marry them. Th1s ralses 1mportant questions for further exploration: Are AA women orlginally from the ranks of the NA group? Is the difference between the AN and AA groups produced because $\mathrm{AA}$ tend to be primary alcoholics and $\mathrm{AN}$ tend to be secondary alcohollcs, 1.e. thelr alcohollsm is secondary to another personallty disorder (19)?

The unmarrled woman may have avolded the stressful marltal situation, elther by choice or as a product of her personality; or she may formerly have been under that stress but has been divorced or widowed from the situation of AN. Perhaps the stress of being lonely and single is not as disorganlzing as being in a marrlage which is unharmontous.

Demographic factors may also be producing the inverse trend of these data. The exploratory nature of this thesis prevents rigorous control for those factors such as education, class, etc. Nevertheless, 1t is imperative to take the factor of age into account, since it has been shown to be a factor in alcoholism as well as in general personal1ty problens $(18,19)$. Clinical observation (32) indicates that in the nidd le oge years, alcoholism in single women is frequently a product 
of stress experlenced by highly educated career women. As both maxried and single women pass through the middle years, they experience problems of adjustments to aging, e.g., change of appearance, health problems, deaths of family and close friends, feelings of personality stognation and lack of fulfillment through husband, children leaving home. TABIE XI shows a possible relationship of age to the numbers of aboormal scores.

TABLE XI

NUMBERS OF ABNORMAL SCORES BY AGE CATEGORY

\begin{tabular}{|c|c|c|c|c|c|c|c|}
\hline \multirow{2}{*}{$\begin{array}{l}\text { Age } \\
(y r s)\end{array}$} & \multicolumn{7}{|c|}{ Abnormal Scores per Test } \\
\hline & 0 & 1 & 2 & 3 & 4 & $5+$ & Total \\
\hline $18-35$ & 13 & 17 & 16 & 7 & 2 & 11 & 67 \\
\hline $35-50$ & 26 & 25 & 11 & 4 & 7 & 13 & 90 \\
\hline $51+$ & 15 & 7 & 6 & 3 & 5 & 6 & 42 \\
\hline Total & 54 & 49 & 33 & 14 & 14 & 30 & 194 \\
\hline
\end{tabular}

The ch1 square of 12.447 , while not significant at $P<.30$, suggested to the investigator that age may be entering into the relationship of marital status and spouse to personality dysfunction. In spite of the Insignificant results, chi square tests were performed while holding age groups constant. The results are shown in TABLES XII, XIII, and XIV. 
TABLE XII

NUMBERS OF ABNORMAL SCORES PER TEST

IN YOUNG ALCOHOLIC WOMEN

\begin{tabular}{l|c|c|c|c|c|c|c}
\hline $\begin{array}{c}\text { Type } \\
\text { of } \\
\text { Woman }\end{array}$ & \multicolumn{7}{c}{ Abnormal Scores per Test } \\
\cline { 2 - 8 } & 0 & 1 & 2 & 3 & 4 & $5+$ & Total \\
\hline AN & 0 & 1 & 3 & 2 & 0 & 2 & 8 \\
\hline AO & 0 & 2 & 1 & 0 & 0 & 0 & 3 \\
\hline AA & 0 & 2 & 2 & 0 & 0 & 2 & 6 \\
\hline Total & 0 & 5 & 6 & 2 & 0 & 4 & 17 \\
\hline Gamma & -.23 & & & & & & \\
\hline
\end{tabular}

In the age range fron elghteen to thirty-five years the sample becomes quite small and the correlation, although in the same direction as the total sample, is insignificant. It is interesting to note that there are no normal tests in this group, but the trend 18 to less rather than more disorganization with the majorlty of frequencies in In the "l" and "2" columns.

For the women between the ages of thirty-81x and fifty the same trend 1s demonstrated, but the results are insignifioant with a ch1 square of 7.023 . 
TABLE XIII

NUMBERS OF ABNORMAL SCORES PER TEST IN MIDDLE-AGED ALCOHOLIC WOMEN

\begin{tabular}{l|c|c|c|c|c|c|c}
\hline \hline \multirow{2}{*}{$\begin{array}{c}\text { Type } \\
\text { of } \\
\text { Woman }\end{array}$} & \multicolumn{7}{c}{ Abnomal Scores per Test } \\
\cline { 2 - 8 } & 0 & 1 & 2 & 3 & 4 & $5+$ & Total \\
\hline \hline AN & 1 & 3 & 3 & 1 & 0 & 3 & 11 \\
\hline AO & 3 & 6 & 2 & 1 & 3 & 3 & 18 \\
\hline AA & 3 & 4 & 2 & 1 & 0 & 1 & 11 \\
\hline Total & 7 & 13 & 7 & 3 & 3 & 7 & 40 \\
\hline
\end{tabular}

$\operatorname{Gamma}=-.25$

TABLE XIV

NUMBERS'OF ABNORMAL SCORES PER TEST IN OLDER ALCOHOLIC WOMEN

\begin{tabular}{l|c|c|c|c|c|c|c}
\hline \hline $\begin{array}{c}\text { Type } \\
\text { of } \\
\text { Woman }\end{array}$ & \multicolumn{7}{c}{ Abnormal Scores per Test } \\
\cline { 2 - 8 } & 0 & 1 & 2 & 3 & 4 & $5+$ & Total \\
\hline AN & 0 & 2 & 1 & 2 & 0 & 5 & 10 \\
\hline A0 & 2 & 2 & 1 & 0 & 0 & 1 & 6 \\
\hline AA & 2 & 2 & 1 & 0 & 1 & 0 & 6 \\
\hline Total & 4 & 6 & 3 & 2 & 1 & 6 & 22 \\
\hline Geima & -.59 & & & & & & \\
\hline
\end{tabular}


In the alcoholic women over fifty-one years of age the trend becomes more definite, with Gama $=-.59$. For older alcoholic women, then, marriage to a non-alcoholic husband has some type of relationship to amount of personality disorganization as measured on the MMPI marriage to an alcoholic spouse is related to significantly less dysfunction: and single alcoholic women seem to fall between the two types of married women. The small sample size prevents the making of conclusions as to the nature of these relationships, but some speculations can be made.

As has previously been noted, younger alcoholic women tend to exhibit less social integration (7). The women in that age group would also have had little chance to develop primary alcoholism and this would tend, therefore, to select women whose alcoholism is secondary to other psychiatric 1llness. The middle and older age groups likely contain a mixture of types. By comparing the frequencies of only the AA and AN categorles for the middle and older age groups, one sees that for both age groups the AN sample tends to fall more toward the "5+" category and the AA sample toward the normal category, Indicating that the AN category may tend to select the secondary alcoholics and AA the primary alcoholics. That 1s, the alcoholic women married to alcoholics may have become alcoholic after many years of drinking with their husbands rather than as a result of marital problems. The investigator speculates that this may be a reallstic adjustment to marriage for those women. The women married to non-alcoholic men may be experiencing the marltal stress which is precipitating drinking behavior, which in turn exacerbates the marltal problems. In summary, both AN and AA women are 
possibly handling marital stress by drinking; for one group the drinkIng perpetuates stress, and for the other group drinking affords a type of marital adjustment.

A I1kely possibility in the middle and older age groups is that the women in the $A N$ and $A O$ categorles are more allke than are the $A N$ and AO groups in young alcoholics, since a larger number of the unnarrled women have had time to experlence divorce and death of spouse when compared to the young unasried women. 


\section{CHAPTER VI}

\section{CONCLUSIONS AND RECOMMENDATIONS}

A group of women seen at a public alcoholism treatment clinic were divided into four categorles (non-alcoholic wives of alcoholic men, alcoholic wives of non-alcoholic men, single alcoholic women, and alcoholic wives of alcoholic men) and compared for amount of personality disorganization, using number of abnormal scales on the clinical prof1les of the Minnesota Multiphasic Personality Inventory administered at the beginning of treatment. The investigator hypothesized that the alcoholic wives of alcoholics would demonstrate the most dysfunction, due to the unstabllizing effects of the alcoholic husband and the stress of marital interaction between two disorganized personalities. In contrast, the alcohollc woman married to the non-alcohollc husband would experience less stress and consequently less personality dysfunction without the problems of an alcoholic husband. The dysfunction of the single alcoholic woman was hypothesized to fall between the two marital categorles, and the dysfunction of the non-alcoholic wife of the alcohollc male was hypothesized to be the least among the four categorles. since these wives have been shown to have essentially normal personallties which become disorganized by their husbands' alcoholic episodes.

As hypothesized, the non-alcoholic wives showed the least anounts of personality disorganization, but the alcoholic women showed an inverse relationship to the hypothesized oxder of dysfunction, 1.e. the 
alcohollc women married to non-alcohollc men were most disorganized, according to numbers of abnormal MMPI scales, followed by the single alcoholic women and then the alcoholic wives of alcoholic men. The differences among the alcoholic groups disappear, though, when age 18 held constant, except in the group of older alcohollc women where the inverse relationship remains.

The exploratory nature of the study precluded the precise measurment of personality variables or rigorous examination of demographic and etfological factors. Nevertheless, some questions have been raised concerning the types of women found in these marital/spouse categorles: Are the older AA women alcoholics only as the result of adjustment to their marital situation? Which of the NA women later become alcohol1cs? How do the personalities of alcoholic women vary according to mar1tal/spouse categorles? Do certain types of alcohollc women tend to remain single, or to marry other alcoholics? Is stress a precipitatIng factor in the alcoholism of the various types of women, and if so, what kinds of stress preclpitate alcohollc eplsodes in the varlous categorles? A closer analysis of demograph1c varlables, nurbers of marr1ages, and specific MPI profiles in conjunction with clinical 1mpressions of these women could begin to answer some of these questions. 
REFERENCES

1. Rathod, N. H. and Thomson, I. G. "Women Alcoholics: A Clintcal Study," Quart. J. Stud. Alc., 32, 45-52, 1971.

2. Curlee, J. "Alcohol1sm and the 'Empty Nest," Bull. Menninger Cl1n., 33. 165-171, 1969.

3. Bbiszörmény1, Z. and Srágl1, G. "On the Problem of Alcohollsm in Women," Ideggy6gy. Szle, Bp. 13, 289-300, 1960.

4. McCord, W1ll1an and MoCord, Joan. Orlgins of Alcohol1sm. Stanford \& Stanford Untversity Press, 1960.

5. McClelland, Dav1d C. "Wanted: A New Self-Image for Women," In Lifton, R. J. (ed.). The Woman In Amerlca. Bostons Beacon Press, 1964.

6. Kinsey, Barry A. The Female Alcohollc. Springfield, Ill.8 Charles C. Thomas, 1966.

7. L1sansky, E. "Alcohollsm In Women, Soclal and Psych1atric Concomitants," Quart. J. Stud. Alc.. 18:588-623, 1957.

8. Berner, P. and Solms, W. "Alkohol1smus bel Frauen (Alcoholism in Women)." Wien. 2. Nervenhe1lk., 6:275-301, 1953.

9. Schuck1t, Marc. "The Alcohollc Woman, A Literature Rev1ew," Psychiatry in Medic1ne, 3,37-43, 1972.

10. Winokur, G., Clayton, P. "Family H1story Studies IV. Comparison of Male and Female alcohollcs," Quart. J. Stud. Alc. 29:885891. 1968.

11. Wall, J. H. "A Study of Alcohol1sm in Women," Amer. J. Psych1atry, 93:943-955, 1937 .

12. Rosenbaum, B. "Married Women Alcohol1cs at the Wash1ngtonian Hosp1tal," Quart. J. Stud. Alc., 19:79-89, 1958.

13. Wood, H. P. and Duffy, E. L. "Psychological Factors in Alcohollc Women," Amer. J. Psychiat., 123,341-345, 1966.

14. Sclare, A.B. "The Fomale Alcohol1c," Brit. J. Add1c., 65:99107, 1970.

15. Zelan, S, L., Fox, J., Could, E.., et al. "Sex-contingent Differences Betreen Male and Female Alcohol1cs," J. Cl1n. Paychol., 228 $160-165,1966$. 
16. Curran, F. "Personality Studies in Alcoholic Women," J. Nerv. Ment. D18., 86:645-663, 1937.

17. Lovine, J. "The Sexual Adjustment of Alcoholics: A Clinical Study of a Selected Sample," Quart. J. Stud. Alc.. 16:675$680,1955$.

18. Cramer, J. J. and Blacker, E. "Social Class and Drinking Experiences of Female Drunkenness Offenders," J. Health Hum. Behav.. $7: 276-283,1966$.

19. Fort, T. and Porterfield, A. L. "Some Backgrounds and Types of Alcoholism Among Women," J. Health Hum. Behav., 2:283-292, 1961.

20. Dahlstrom, W. G. An MMPI Handbook. Minneapolis: University of Minnesota Press, 1966.

21. Schilder, P. "Discussion of Paper by. Wall, J. H., A Study of Alcoholism in Women," Amer. J. Psych1at., 93.953, 1937.

22. Jackson, J. K. "The Adjustment of the Fam1ly to the Cr1sis of Alcohol1sm," Quart. J. Stud. Alc.. 15:562-586, 1954.

23. Balley, M. B., Haberman, P. W., and Alksne, H. "The Epldemiology of Alcoholism in an Urban Residential Area," Quart. J. Stud. Alc., $26+19-40,1965$.

24. Edwards, P., Harvey, C., and Whitehoad, P. C. "W1ves of Alcohollcs" quart. J. Stud. Alc., 34,112-132, 1973.

25. Wanberg, K. W. and Horn, J. L. "Alcohol1sm Symptom Patterns of Men and Women," Quart. J. Stud. Alc., 31,40-61, 1970.

26. Wanberg, K. W. and Knapp, J. "Differences in Drinking Symptoms and Behavior of Men and Women Alcoholics," Brit1sh J. Addiction, $64: 347-355,1970$.

27. Študent, V. and Matová, A. "Vývoj Psychlcḱkých Poruch u Manželek Alkoholikú (Development of Mental Disorders in Wives of Alcohol1cs)," Csl. Psych1at. 65:23-29, 1969. Abstracted in Quart. J. Stud. Alc.. 31:757-758.

28. Fort, T. and Porterfield, A. I. "Some Backscounds and Types of Alcoholism among Women," J. Health Hum. Behav., 2:283-292, 1961.

29. Malzberg, B. "Marital Status and Mental Disease," Int. J. Soc. Psychiat., $10: 19-26$.

30. Ballard, R. G. "The Interaction between Mar1tal Conflict and Alcohol1sm as Seen Through MMPI's of Marrlage Partners," Symposium, 1958. Amer. J. Orthopsychiat., 29:528-546, 1959. 
31. Dlagnostic and Statistical Manual of Mental Disonders (Second ed1tion). Washington: American Psychiatric Association, 1968.

32. Nelson, Norma. Unpublished clinical observations. Portland State Un1versityi Graduate School of Soc1al Work. 1974.

33. Bailey, M. B. "Research on Alcohollsm and Marriage," in Social Work Practice. NeH York I Columbia University Pres8, 1963. 
OTHER SOURCES CONSULTED

Bacon, S. D. "The Process of Addiction to Alcohol, Soclal Aspects," Quart. J. Stud. Alc.., 34:1-27, 1973.

Bullock, S. C. and Mudd, E. H. "The Interaction of Alcoholic Husbands and "Their Nonalcoholic Wives During Counseling," Amer. J. Orthopsychiat., 29:519-527.

Cramer, J. J. and Blacker, E. "'Early' and 'Late' Problem Drinkers among Female Prisoners," J. Health Hum. Behav., 4:282-290, 1963.

Curlee, J. "Women Alcohol1cs," Fed. Probation, 32 (No. 1):16-20, 1968.

Curlee, J. "A Comparison of Male and Female Patients at an Alcohol1sm Treatment Center," J. Psychol. 74:239-247, 1970.

Fox, R. Alcoholism, Its Scope, Cause and Treatment. New York, Random House, 1955.

Haberman, P. W. "Psychological Test Score Changes for W1ves of Alcoholics during Perlods of Drinking and Sobriety," J. Clin. Psychol.., 20:230-232, 1964.

Haberman, P. W. "Some Characterist1cs of Alcoholic Marriages Differentlated by Level of Deviance," J. Marriage Fam., 27:34-36, 1965

James, J. E. and Goldman, M. "Behavior Trends of W1ves of Alcohollcs," Quart. J. Stud. Alc., 32:373-381, 1971.

Johnson, M. W., DeVries, J. C. and Houghton, M. I. "The Female Alcohol1c," Nurs. Res.. Ph1lad. 15:343-347, 1966.

Kinsey, Barry A. The Female Alcoholic. Springfield, Charles C. Thoma 1966.

Kinsey, Barry A. "Psychologocal Factors in Alcohollc Women from a State Hosp1tal Sample," Amer. J. Psych1at. 124:1463-1466, 1968.

Kogan, K. L. and Jackson, J. K. "Role Perceptions in W1ves of Alcoho11 cs and of Nonalcoholics," Quart. J. Stud. Alc., 24,627-239, 1963.

Kogan, K. L, , Fordyce, W. E. and Jackson, J. K. "Personal1ty D1sturbance in Wives of Alcohollcs," Quart. J. Stud. Alc., 24:227238, 1963.

Kogan, K. L. and Jackson, J. K. "Patterns of Atypical Perceptions of Self and Spouse in Wives of Alcohollcs," Quart. J. Stud. Alc., 25:555-557, 1964. 
Kogan, K. L. and Jackson, J. K. "Stress, Personallty and Emotional Disturbance in W1ves of Alcohollcs," Quart. J. Stud. Alc., $26: 486-495,1965$.

Kogan, K. L. and Jackson, J. K. "Some Concomitants of Personal Diff1cult1es in W1ves of Alcoholics and Nonalcoholics," Quart J. Stud. Alc., 26:595-604, 1965 .

Lemert, E. M. "The Occurrence and Sequence of Events in the Adjustment of Families to Alcohollsm," Quart. J. Stud. Alc., 218 679-697, 1960.

Lindbeck, V. L. "The Woman Alcoholic: a Review of the LAterature," Int. J. Add1ct., Vol. 7, \#3, 1971.

Llsansky, E. L. "The Woman Alcohollc," Ann. Amer. Acad. Pol1t. Soc. Sc1.. 315:73-81, 1958.

MacDonald, D. E. "Mental Disorders in W1ves of Alcoholics," Quart. J. Stud. Alc., 17:282-287, 1956.

Myerson, D. J. "Clinical Observations on a Group of Alcohollc Prisoners," quart. J. Stud. Alc., 20:555-557, 1959.

Myerson, K. J. "A Therapeut1c Appra1sal of Certain Married Alcohollc Women," Int. Psych1at. Clinc., Boston 3:143-157, 1966.

National Counc1l on Alcoholism, Criteria Committee. "Criteria for Diagnosis of Alcoholism," Amer. J. Psychiat., 129:127-235. 1972.

Palge, P. E., LaPointe, W., and Krueger, A. "The Marital Dyad as a Diagnostic and Treatment Varlable in Alcoholic Addiction," Psychology, $8: 1,64-75$.

Parker, F. B. "Sex-role Adjustment in Women Alcohollcs," Quart. J. Stud. Alc.. 33,647-657, 1972 .

P1ttman, D. J a and Snyder, C. R. Soclety, Culture, and Drinking Patterns. New York 8 John W1ley and Sons, Inc., 1962.

Rae, J. B. and Forbes, A. R. "Clinical and Psychometric Character1stics of the Wives of Alcoholics," Brit. J. Psychiat., 112:197$200,1966$.

Schuck1t, M., P1tts, F. N. ot.al. "Alcohol18m. I. Two Types of Alcohollsm in Women," Arch. Gen. Psychtat., 20:301-306, 1969.

Sclare, A. B. "The Fomele Alcohol1c," Brit. J. Add1ct., 65:99-107. 1970. 
Senseman, L. A. "The Houserife's Secret Illness; How to Recognize the Female Alcohollc," R. I. Med. J. 49,40-42, 1966.

Sherfey, M. J. "Psychopathology and Character Structure in Chronic Alcohollsm," In Diethelm, 0. (ed.). Etiology of Chronic Alcohollsm. Springfield, Ill, Charles C. Thomas, 1955.

Splogel, D., Hadley, P.A. and Hadley, R. G. "Porsonallty Test Patterns of Rehabilitation Center Alcohol1cs, Psych1atric Inpatients and Normals," J.Cl1n. Psychol., 26,366-371, 1970.

Winokur, G., Rimmer, J. and Relch, T. "Alcoholism. IV. Is There More than One Type of Alcoholism?" Brit. J. Psych1at., 118:525531. 1971.

Wolf, I. "Alcohollsm and Mrrage," Quart. J. Stud. Alc., 19:511513. 1958. 